CATALAN REVIEW

Catalan Review

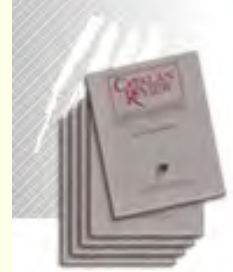

You are accessing the Digital Archive of the Catalan Review Journal.

By accessing and/or using this Digital Archive, you accept and agree to abide by the Terms and Conditions of Use available at http://www.nacs-

catalanstudies.org/catalan review.html

Catalan Review is the premier international scholarly journal devoted to all aspects of Catalan culture. By Catalan culture is understood all manifestations of intellectual and artistic life produced in the Catalan language or in the geographical areas where Catalan is spoken. Catalan Review has been in publication since 1986 .
NORTH

AMERICAN

CATALAN

SOCIETY
Esteu accedint a l'Arxiu Digital del Catalan Review

A l' accedir i / o utilitzar aquest Arxiu Digital, vostè accepta i es compromet a complir els termes i condicions d'ús disponibles a http://www.nacs-

catalanstudies.org/catalan review.html

Catalan Review és la primera revista internacional dedicada a tots els aspectes de la cultura catalana. Per la cultura catalana s'entén totes les manifestacions de la vida intel lectual i artística produïda en llengua catalana o en les zones geogràfiques on es parla català. Catalan Review es publica des de 1986.

\title{
La gran encisera: Three Odes to Barcelona, and a Film Josep Miquel Sobrer
}

Catalan Review, Vol. XVIII, number 1-2, (1998), p. 121-128 


\section{LA GRAN ENCISERA: THREE ODES TO BARCELONA, AND A FILM}

JOSEP MIQUEL SOBRER

\section{ABSTRACT}

Three odes to Barcelona, written by Jacint Verdaguer, Joan Maragall, and "Pere Quart" Joan Oliver] respectively, make clear the changing faces of the city. For Verdaguer, Barcelona is an expansive metropolis on its way to greatness. For Maragall, Barcelona, while rocked by conflict, remains the inescapable center and "great enchantress" of Catalan life. For Pere Quart, Barcelona is the locus of a sweeping revolution aimed at bringing about a new social order - a hope promptly shattered by the Spanish war of 1936-39. The three odes roughly correspond to three generations and offer a poetic history of the city. Skipping a generation and shifting from poetry to film, the article addresses Barcelona at the turn of the twentieth century as seen by Pedro Almodóvar in his 1998 Oscar-winning film, Todo sobre mi madre. In Almodóvar's portrait, Barcelona is detached from its role as Catalan capital and becomes a globalized city for postmodern pilgrimages. As if to underscore this move, the celebrated technique known as trencadis employed by Gaudí and other modernists (and consisting of broken pieces of ceramic put together to form new ornamental compositions) serves as a symbolic backdrop to a number of characters who flock to the city to give new meaning to their fragmented selves.

Wh hatever else Catalonia might be, it is a macrocephalic organism, its head being the city of Barcelona. Barcelona is the biggest human conglomeration on the shores of the Mediterranean, its metropolitan area holds $83 \%$ of the population of Catalonia (Mestre and Hurtado 264). Today the city is more recognized than its country in the imaginary of an affluent and roaming international "community," Barcelona is "in." But Barcelona is also the head that devours its own body, relegating its hinterlands to the status of suburbs. Yet this rise of the city does not seem to upset Catalans in general. Having failed to build for themselves a nation-state, Catalans have transferred the focus of nationalist desire to their capital city. As Barcelona grows in population and as admiration for its architecture grows among foreigners, the aspiration for an independent Catalan nation wanes. The apparent success of the city in the international imaginary has wrestled the title of primary identity away from its haggard and laggard nation

One of the first to pay attention to the growth of symbolic power 
for Barcelona was Jacint Verdaguer, the Catalan "national" poet. In 1883 Verdaguer competed, successfully, in the Jocs Florals (poetic competitions) with a rather bombastic poem, "A Barcelona," which he himself defines in a footnote as an "oda," an ode, a poem of praise. The poem, following an epigraph consisting of the well-known tribute to the city from Cervantes's Quijote (with no apparent consciousness of its possible irony), begins as follows: "Quan a la falda et miro de Montjuic seguda." The poem's meter is the same that Verdaguer had used in his epic success of 1877, L'Atlàntida: quatrains (46 in the Oda) of 13-syllable verses, which are the Catalan equivalent of the French alexandrines.

Verdaguer wrote his "Oda" in a moment of personal and collective euphoria: "Lo teu present esplèndid," (I8I) in the poet's own words. His triumph at the Jocs Florals of 1877 with L'Atlantida marks a change in Verdaguer's vision of the city, from sinful Babylon to the red-carpet site of his literary success. For the city, the moment was also propitious: the old ramparts had been torn down (1854) and the Eixample begun in 1859 . By the end of 1869 (that is to say, shortly after the revolution of 1868 ), the hated Ciutadella fortress had been given to the city to tear down and its land to be made into a park. Verdaguer clearly alludes to the latter event in lines $123-124$ of his "Oda": "la Ciutadella / per fer de jardinera ses armes trossejant." By the i 880 os the city was also acquiring electric lights and preparing for the Universal Exposition of 1888 . All these euphoric developments beget hyperbole:

Llavors, llavors al témer que el vols per capçalera, girant los ulls als Alpes, lo Pirineu veí demanarà, eixugant-se la blanca cabellera, si la París del Sena s'és transplantada aqui. (73-76)

Parisians may breathe easy, however, as the next stanza begins with a resounding "No."

What makes Verdaguer's "Oda" more notable than its literary achievement is its position in Catalan literary history, including Verdaguer's own poetic trajectory. For Verdaguer, "A Barcelona" (the title of the ode) comprises a bridge between his two epic poems, the mythical Atlantida and the historical Canigó (1885). The final alexandrine of the "Oda," "Qui enfonza o alça els pobles, és Déu que els ha creat"(184) prefigures the ending of Canigó where the clock towers of two monastic churches recap in their dialogue the historical destiny of a Catalonia united under God.

Otherwise, "A Barcelona" spans two literary moments in Catalan letters: the Renaixença and Modemisme. From its very beginning, Verdaguer's ode, with its bird's-eye-view of the geography of the city, links itself to the archetypal poem of the Renaixença, Aribau's 'La Pà- 
tria" of 1833 , a composition whose author subtitled it humbly as "Trobes" ("verses"), but which soon acquired the title "Oda a la Pàtria." Like Aribau, Verdaguer refers to Montjuïc and to the mountains of the interior: Montseny, Montserrat, and the Pyrenees. Unlike Aribau, who took a personal stance in the poem, Verdaguer remains epic in scope, prophetic in tone, and direct in his allusions - to topography, church buildings, and contemporary figures, Verdaguer refers by name in the "Oda" to the philosopher Jaume Balmes (IOI), the sculptor Damià Campeny (103), and the painter Mariano Fortuny, père (Io4). Barcelona, for Verdaguer, is the crux where the chthonic, the political, the economic, and the intellectual meet and mingle amid an ever-growing population (the city more than doubled in number of inhabitants between 1857 and 1900 [Vila 418 ]). As opposed to Aribau's, Verdaguer's is truly an ode, a song of praise - of praise to the growing metropolis with enough enthusiastic copy for a tourism pamphlet, complete with references to its benign climate: "ni eix cel que fóra un dia ma tenda de campanya, / ni eix sol que fóra un dia faró del meu vaixell" ( $\left.17 \mathrm{I}^{-72}\right)$. At the other end of literary history, Verdaguer's "A Barcelona" links directly with a composition by Joan Maragall, the one bearing the key word, "oda," in its title, which, like its opening verse, constitutes a clear and direct allusion to Verdaguer's work.

Indeed, Maragall's "Oda nova a Barcelona," written in 1909, begins with Verdaguerian alexandrines, the personification of the city, and a similar admiration for the growth of the metropolis:

-On te'n vas, Barcelona, esperit català

que has vençuc la carena $i$ has saltat ja la tanca

i te'n vas dret enfora amb tes cases disperses,

lo mateix que embriagada de ta gran llibertat? (I-4)

The opening dash indicates that the ode is a dialogue, and in the second quatrain Barcelona itself answers the poet:

-Veig allà el Pirineu amb ses neus somrosades,

i al davant Catalunya tota estesa als seus peus,

i me'n vaig. ... És l'amor qui m'empeny cap enfora,

i me'n vaig delirant amb els braços oberts. $(5-8)$

This declamatory Verdaguerian beginning, however, was soon broken. Maragall had begun composing the poem on February 4, 1909 (Benet 97), but he interrupted the writing in the middle of line 25 . In the notebook where the first draft is preserved, after the start of the line "Corre enllà, corre enllà," Maragall wrote: "revolució," One could venture that so charged a word as "revolució" marks the death of the more placid and folkloric Renaixença. 
That "revolució," most densely materialized as the "Tragic Week" of July 1909, broke the poem as it broke the city. The placid rhythm of Maragall's "Oda nova," with its regular alexandrines, soon turns chaotic and sour. The poet blasts the city: "ets covarda $\mathrm{i}$ crudel $\mathrm{i}$ grollera, / Barcelona, però ets riallera." The rhythm breaks down, as the well-composed hypotactic verses give way to the paratactic enumerations that characterize the end of the poem: "se'n riu i flastoma i es baralla i s'esventa" (90); "que ets vana i coquina i traidora i grollera" (97). In the poem, as in the city, a motley multitude erupts and creates a new syntax, a new reality - a reality of violence and blood, of mud and fire. The frivolous, voluble city has burst out in "riallades de sang" (59).

In Maragall's view, worse than the revolt (which he did not witness firsthand) is the repression, emblematized by the fortress and execution grounds atop Montjüc:

I tens dreta en la mar la muntanya, ai!, que venja amb son castell al cim, i amb la revenja mes ai! en el flanc! (64-66)

The geological, topographical, and largely romantic views of Monjuïc by Aribau and Verdaguer no longer stand. The city is now a living, aching reality. Maragall understands healing, rather than prophesying, to be his role as poet.

An ironic detail of the Tragic Week was the benign weather it enjoyed. Enric de Fuentes, one of Maragall's informants (Maragall had been summering in Caldetes), wrote: "I per damunt de la ciutat el sol, en un cel esplèndid de blavor ens il-lumina i ens enlluerna" (quoted in Benet 72). The contrast between the violence in the streets and the placid clarity of the sky becomes for Maragall a sign of divine forgiveness and the inspiration for his own reaction to the events. The blue sky is at once a symbol of benevolent justice and of awareness of life. So, after seeing hope in the emerging temple of Gaudís Sagrada Família, Maragall closes his poem with a hymn to twentieth-century Barcelona, a city to be accepted as "ours": "Barcelona! i amb tos pecats, nostra! nostra! / Barcelona nostra! la gran encisera!” (99-100).

The next great poet to write an ode to the city was "Pere Quart," the pen name that Joan Oliver used when publishing his poems. As if to go one up on the timing of his predecessors, Pere Quart's "Oda a Barcelona" was published in 1936, at the onset of the Civil War. The poem, like Verdaguer's, was also issued as a pamphlet, but in order to mark his political distance from his two predecessors, Pere Quart's "Oda" was printed in white ink over red paper (Turull 49) and published by the Comissariat de Propaganda of the Republican Generalitat. The poem was re-issued the following year, but still bearing 
the date August 1936, in volume VII of Hora de España in Valencia. Pere Quart's allegiance to the Revolution, its fervor and hopes (he also wrote the lyrics for the hymn of the 'Exèrcit Popular Catala'), set him apart from his predecessors, for he viewed Barcelona essentially as a politically committed citizen rather than an oracular voice.

Despite his leftist stance, the similarities with Maragall's "Oda nova" are clear. Foremost are the frequent and direct invocations of a personified Barcelona, uttered not without paternalistic condescension. For Maragall, Barcelona was "una menestrala pervinguda / que ho fa tot per punt" (33-34). "She" wears a nun's veil and a fashionable lady's outfit (47), yet is fickle and morphs into a "marmanyera endiablada," setting convents on fire only to rebuild them. At the end of the day, Barcelona is scolded by a loving Maragall: "ets vana i coquina i traïdora i grollera," and yet, as already noted, "amb tos pecats, nostra! nostra! / Barcelona nostra, la gran encisera!" (99-100)

Maragall appointed himself the forgiving father of the prodigal daughter, but the tone employed by Pere Quart does not lie very far away. His Barcelona is also fickle, Protean, a "monja llamenca" who struts the elite neighborhoods in proletarian clothes. Above all Barcelona is mother, rather than daughter, but she is also the admonished object of a comminatory set of imperatives with which the poem ends:

Treballa. Calla.

Malfia't de la història.

Somnia-la i refés-la.

Vigila el mar, vigila les muntanyes.

Pensa en el fill que duus a les entranyes. (I44-48)

The rhythm is irregular, seemingly broken, not unlike Maragall's. Pere Quart's poem strikes a contrast with the rest of his production -urbane and ironical. He himself, in 1949, qualified his poetry as "aseptic, with no pathogenic elements, an automatic process of intellectual chemistry" (Oliver 453-54).

Yet for the 1963 volume of his collected poems, Obra de Pere Quart, his "Oda" was reworked considerably. He eliminated some fiery and -in the light of history - patently unprophetic lines such as:

Seràs si vols la capital altiva de la petita Rússia d'Occident

U ERRA ESSA HAC

"Unió de Repúbliques Socialistes

Hispàniques."

And he reorganized the poem's lines into a new set of groupings (I call them groupings rather than stanzas as they seem to obey the 
development of the poem's logical thought rather than anything having to do with meter or rhythm). The 1963 version was essentially repeated in the 1975 Obra poètica de Pere Quart, published by Edicions Proa. This latter version was dubbed definitive by the author.

Pere Quart's Barcelona is, in short, the pregnant mother of the revolution. "Revolution" (or rather. "revolució") is what the Catalans of 1936 called what we now call the Spanish Civil War. And this "revolution" is the protagonist of the poem that tries to portray a mixture of violence and hope. Social change - and here Pere Quart parts from Maragall- is desirable: "el tumult és ordre" (17). The bourgeoisie ("fills teus ... enguantats, clenxinats" [33-35]) have turned their backs on the revolutionary city while the revolutionaries take it over. A single image, curiously subtle for a composition of this nature, sums it up: "les catifes comuniquen / tímides queixes a les espardenyes" (64-65); the rope-soled soft espardenya, as opposed to the leather sabata, was the symbol of the working class; a poster of the time, a photomontage by Pere Català i Pic, features an espardenya-shod foot smashing a swastika.

Pere Quart's is an ode to Barcelona's labor, in both senses of the word: to the revolutionary working class and to the birth pains for " $\mathrm{el}$ fill que duus a les entranyes"(148). Indeed, the city gives birth to a new social order (both socialist and Catalanist) and to a new esthetic, of which the "Oda" itself is a harbinger:
Al cap d'anyades
t'arribarà l'eco:
sospirs, gemecs, renecs, esclats,
sanglots, udols, xiscles, esclats!
I ja tindràs l'himne triomfal
sota la bandera de la quàdruple flama. (II4-19)

But of course that Barcelona - socialist and Catalanist - died giving birth. Accordingly, it is in homage to Pere Quart's - or Joan Oliver's- optimism that he included his dated and frustrated "Oda" in all the published compilations of his poetry. Only about half a century later would the city give birth to a social reality that somewhat resembles the triumphal hymn prophesied by Pere Quart, but the broken and shrieking esthetic of the "Oda" was to become the norm for the rest of the century.

The three odes discussed above were published, respectively, 26 and 27 years apart; that is to say, they stand one generation apart from each other. Skipping one generation - the sixties-we come, nearing this, our shiny, troubled millennium, to the imaginary of a new Barcelona, the imploded Barcelona of the Olympic games of 1992 and of 
Pedro Almodóvar's Oscar-winning film of 1998 , Todo sobre mi madre, in which the Catalan language appears as mere filler, as inessential and inconsequential to life in contemporary Barcelona. The lady that vanishes is the Catalan language - or rather, the mother of Barcelona, its mother tongue, now vanishes: Todo sobre mi madre, pero sin mi madre, sin mi lengua materna, sense la meva llengua materna. The opening ceremonies of the Olympics presented to the world, through the artistry of La Fura dels Baus and other Catalan groups, an heroic vision not too distant from Verdaguer's. As in Verdaguer's epic poem Atlantida, the hero therein portrayed was Hercules, but unlike Verdaguer's, here, in the Olympics, there was a silent protagonist: for, clearly, the opening ceremony in July of 1992 at the Olympic stadium in Barcelona was aimed at an international audience and was meant not as discourse but as spectacle.

In Almodóvar's Todo sobre mi madre, which takes place mostly in Barcelona, the Catalan language is barely heard. One of the characters, Rosa's mother (played by the consummate Catalan actress Rosa Maria Sardà) addresses her dog in Catalan, but she addresses her daughter, husband, and everyone else in Castilian. In a scene in a bar towards the end of the movie one hears a few background fragments of conversation in Catalan-and that's all, folks. Still, Barcelona has a clear and strong presence in the film. The protagonist, Manuela, escapes to Barcelona (as, she declares, she had escaped from Barcelona to Madrid 17 years before). She travels between the cities by train (but she flies to A Coruña in a brief scene), and the camera shows the train's rapid movement through a tunnel; the symbolism of a new being's delivery through the birth canal comes inevitably to mind.

Almodóvar's Barcelona is, then, a place of transformation. Interestingly, Madrid, in this film, is a static city and Barcelona the dynamic site where all change occurs. And those changes are quite radical. It is in Barcelona that two men become women, that a nun gets pregnant and is infected with AIDS, and that two other characters undergo important psychological changes before moving back to Madrid. By the same token, Barcelona is also the place where make-believe becomes real and where transformation carries a price tag. In Barcelona, human personality is placed squarely in a system of economic exchange not without tergiversation. Manuela dresses as a prostitute, and is taken as one, before she can regain her lost equilibrium. Sister Rosa's mother earns her living by forging paintings by Marc Chagall. And foremost among these shifts and deceptions, we have Agrado, Manuela's transvestite friend who delivers - in lieu of a performance of A Streetcar Named Desire - a hilarious monologue in which each part of her body, including her breasts, is calibrated according to the pesetas she has spent. In her monologue, Manuela accepts her 
commodification and creates her own hagiography as, so to say, Maria del Agrado, Virgen de las pesetas. Visually too, the shots of Barcelona underscore notions of change and transformation. A multitude of prostitutes and their johns move about as busily and as tensely as a circle of wagons under Indian attack in an old Western. The modernista architecture and even, in one scenario, the busy wallpaper -cluttered, complex, mosaic-like, and fluctuating - completes the jarring, transformative visuals of the film. Barcelona is here a kaleidoscope.

Todo sobre mi madre is an apt portrayal of what the imploded Barcelona has become. The city is no longer Cap $i$ Casal, the center of a nation. It has turned into a place of pilgrimage, a site of personal transformation, a place where the old language is but one more of the dizzying layers of complexity, an element in its décor, a shard of tile in the city's trencadis. You come to Barcelona to be dazzled by Gaudi and the Rambla, by the juxtaposition of old and new, by the contrast between the grayness of a metropolis and the brightness of the Mediterranean coast. You come to Barcelona to discover yourself (whoever you might be or want to be) more than to discover it. You come to Barcelona to leave your old skin and get a new one, as shiny and complex as the most intricate trencadis. You come to find your self. Barcelona is now the "orgasmatron" of the new global soul. Joan Maragall proved to be prophetic: his city (he was born in the "ciutat vella") has indeed become "la gran encisera."

JOSEP MIQUEL SOBRER INDIANA UNIVERSITY

\section{WORKS CITED}

BENET, Josep. Maragall i la Setmana Tràgica. Barcelona: Edicions 62, $4^{\text {th }}$ ed., 1968.

Mestre i Campí, Jesús and Víctor Hurtado, eds. Atles Històic de Catalunya. Barcelona: Edicions 62, 1995.

Oliver, Joan. Obres completes. Vol.r: Obra poètica de Pere Quart. Barcelona: Proa, 1975

TERRY, Arthur. La poesia de Joan Maragall. Barcelona: Editorial Barcino, 1963.

Turull, Antoni. Pere Quart, poeta del nostre temps. Barcelona: Edicions 62,1984 .

Verdaguer, Jacinto. Obres completes. Barcelona: Biblioteca Perenne. 1946.

Vila Dinares, Pau, and Lluís CASAsSAs Simo. Barcelona i la seva rodalia al llarg del temps. Barcelona: Aedos, 1974. 